\title{
Badania kliniczne w obliczu nowych przepisów Unii Europejskiej, nowe możliwości realizacji niekomercyjnych badań klinicznych w Polsce
}

\author{
Agnieszka Byszek ${ }^{1}$, Piotr Rutkowski ${ }^{1,2}$
}

Badania kliniczne stanowią podstawowy czynnik dla postępu wiedzy w naukach medycznych (w tym — w onkologii) i są realizowane w ściśle określonych warunkach prawnych i etycznych. W celu wzrostu liczby badań klinicznych prowadzonych na terenie państw członkowskich UE w czerwcu 2014 roku weszło w życie Rozporządzenie Parlamentu Europejskiego $\mathrm{nr}$ 536/2014. Rozporządzenie to ma wprowadzić harmonizację w zakresie regulacji badań klinicznych i obowiązywać ma we wszystkich krajach Unii Europejskiej. Nowe przepisy nie tylko uproszczają procedurę składania wniosków o pozwolenie na badanie kliniczne, skrócą czas otrzymania zgody na przeprowadzenie badania, ale również wprowadzają nowe definicje, jak badanie biomedyczne czy badanie o niskim stopniu interwencji. Szczególnie istotne zmiany dotyczyć będą badań niekomercyjnych, które obejmują akademickie projekty naukowo-badawcze w medycynie lub badania inicjowane przez badaczy (investigator initiated study), realizowane przez uniwersytety, towarzystwa naukowe, naukowe grupy badawcze lub instytuty naukowo-badawcze. Zgodnie z zapisami rozporządzenia konieczne jest podjęcie krajowych działań legislacyjnych, mających na celu wsparcie tego typu projektów. W związku z powyższym towarzystwa onkologiczne w naszym kraju zaproponowały rozwiązania mające na celu usprawnienie realizacji niekomercyjnych badań klinicznych w Polsce.

\section{Clinical trials and the new European Union legislation}

Clinical trials are fundamental for the advancement of knowledge in medical sciences (including oncology) therefore strict legal and ethical conditions should be applied to their planning and conducting. Regulation No 536/2014 of the European Parliament was enforced in June 2014 to increase the number of clinical trials conducted in EU Member States. This new legislation regulates clinical trials and is mandatory in all EU countries. These new rules not only simplify the application procedure for authorization of a clinical trial and shorten waiting time for the authorization to begin study, but also introduce new definitions, including biomedical trials or clinical trials with a low degree of intervention. Particularly significant changes concern non-commercial research, including academic research projects in medicine and trials initiated by investigators (Investigator Initiated Study) based on universities, scientific societies, scientific research groups or research institutes. According to the provisions of the Regulation, it is necessary to take national legislative measures in order to support such projects. Therefore, oncology societes in our country propose means to enhance non-commercial clinical trials to be conducted in Poland.

NOWOTWORY Journal of Oncology 2015; 65, 2: 93-95

Słowa kluczowe: badania kliniczne, niekomercyjne, badania inicjowane przez badaczy, akademickie, rozporządzenie Key words: clinical trials, noncommercial, investigator initiated study, academic, legislation

Badania kliniczne stanowią podstawowy czynnik dla postępu wiedzy w naukach medycznych (w tym — w onkologii) i są realizowane w ściśle określonych warunkach prawnych i etycznych. Spadek liczby badań klinicznych prowadzonych na terenie państw członkowskich Unii Europejskiej (UE) oraz wzrost konkurencyjności Azji i Ameryki Północnej zainicjo-

\footnotetext{
${ }^{1}$ Zespół ds. Badań Klinicznych
}

${ }^{2}$ Klinika Nowotworów Tkanek Miękkich, Kości i Czerniaków

Centrum Onkologii — Instytut im. Marii Skłodowskiej-Curie w Warszawie 
wały wprowadzenie koniecznych zmian w prawodawstwie unijnym. 16 czerwca 2014 roku weszło w życie Rozporządzenie Parlamentu Europejskiego i Rady (UE) nr 536/2014 z dnia 14 kwietnia 2014 r. w sprawie badań klinicznych produktów leczniczych stosowanych u ludzi [1]. Jednocześnie Rozporządzenie to uchyla dyrektywę 2001/20/EW, której implementacja w państwach członkowskich przebiegała na różnym poziomie zaawansowania, co powodowało powstanie różnic w zakresie pracy organów administracyjnych oraz istotne odchylenia w przebiegu procesu rejestracji badań w poszczególnych krajach. Nowe rozporządzenie ma wprowadzić harmonizację w zakresie regulacji badań klinicznych i obowiązywać ma we wszystkich krajach Unii Europejskiej. Związane jest to nie tylko z podniesieniem konkurencyjności państw członkowskich, ale również z kierunkiem rozwoju nowych badań klinicznych, których celem będą populacje pacjentów określone przy pomocy informacji genomicznych. W tego typu badaniach, w celu uzyskania odpowiedniego poziomu rekrutacji, konieczne będzie włączenie kilku państw członkowskich. Nowe przepisy uproszczają procedurę składania wniosków o pozwolenie na badanie kliniczne, tak aby uniknąć wielokrotnego przedkładania w dużej mierze często identycznych informacji i zastąpić je składaniem jednej dokumentacji, ujmującej wszystkie zainteresowane państwa członkowskie, na specjalnie ustalonym do tego portalu. Dodatkowo sponsorzy mogą rozszerzyć prowadzenie badania na inne kraje członkowskie bez konieczności ponownej oceny wniosku, tylko poprzez rozszerzenie obowiązującego pozwolenia. Również czas na ocenę dokumentacji wniosków powinien być na tyle wystarczający, aby zachować przyjęte procedury postępowania, jednocześnie umożliwiając szybki dostęp do innowacyjnych terapii. Rozporządzenie podejmuje kwestię wspierania badań klinicznych służących rozwojowi rzadkich produktów leczniczych, tak aby wnioski rozpatrywane były szybko i efektywnie. Nowością jest również uproszczony sposób uzyskania świadomej zgody w przypadku niektórych badań, których metodologia wymaga, aby do otrzymywania różnych badanych produktów leczniczych wyznaczono grupy uczestników, nie zaś indywidualnych uczestników. W tego typu badaniach wykorzystuje się produkty dopuszczone do obrotu, a poszczególni uczestnicy poddawani są standardowej terapii niezależnie od tego, czy wyrażą zgodę na udział w badaniu, czy odmówią zgody na taki udział, czy też wycofają się z niego. Zatem jedyną konsekwencją nieuczestniczenia jest to, że odnoszące się do nich dane nie będą wykorzystywane do celów badania klinicznego.

Istotną zmianą jest wprowadzenie nowej definicji badania klinicznego, będącego częścią szerszego pojęcia — badania biomedycznego. Badania biomedyczne możemy podzielić na badania kliniczne i badania nieinterwencyjne. Prawodawca wprowadza również pojęcie badania klinicznego o niskim stopniu interwencji, czyli takiego, w którym produkty lecznicze dopuszczone do obrotu stosowane są zgodnie z charakterystyką produktu leczniczego lub ich stosowanie oparte jest na opublikowanych dowodach naukowych, a zastosowane dodatkowe procedury diagnostyczne stanowią minimalne dodatkowe ryzyko w porównaniu ze standardową praktyką kliniczną.

Nowe rozporządzenie w istotny sposób reguluje kwestie związane z niekomercyjnymi badaniami klinicznymi. Definiuje, iż badacz i sponsor mogą być tą samą osobą, a zgodnie z artykułem 59 Rozporządzenia moga istnieć luźne, nieformalne sieci badaczy lub instytucji badawczych, które wspólnie prowadzq badanie kliniczne. Zapis ten jest szczególnie istotny dla niekomercyjnych, akademickich badań klinicznych, które stanowią podstawowy czynnik postępu wiedzy w naukach medycznych, głównie w onkologii. Zgodnie z danymi Europejskiej Agencji Leków 39\% badań klinicznych w dziedzinach związanych z onkologią realizowanych jest $w$ formie niekomercyjnych badań akademickich, które obejmują akademickie projekty naukowo-badawcze w medycynie lub badania inicjowane przez badaczy (investigator initiated study), realizowane przez uniwersytety, towarzystwa naukowe, naukowe grupy badawcze lub instytuty naukowo-badawcze. W Polsce stanowią one poniżej 1\% wszystkich badań. Zgodnie z treścią art. 37ia Ustawy z dnia 6 września 2001 r. <Prawo farmaceutyczne> badanie kliniczne niekomercyjne to takie badanie, w którym właścicielem danych jest sponsor będący uczelnią, placówką naukową posiadającą uprawnienia do nadawania stopni naukowych, zakładem opieki zdrowotnej (sic!), badaczem, organizacją pacjentów, organizacją badaczy lub inną osobą fizyczną lub prawną lub jednostką organizacyjną nieposiadającą osobowości prawnej, której celem działalności nie jest osiąganie zysku w zakresie prowadzenia i organizacji badań klinicznych bądź wytwarzania lub obrotu produktami leczniczymi [2]. Niekomercyjne badania akademickie, w odróżnieniu od komercyjnych, których głównym celem jest wprowadzenie nowego leku na rynek medyczny, ukierunkowane są na poszukiwanie czynników predykcyjnych i stanowią w praktyce jedyną możliwość racjonalizacji i zmniejszenia kosztów leczenia. Zawierają one często cele badawcze, którymi nie jest zainteresowany przemysł farmaceutyczny (np. nowe wskazania dla już zarejestrowanych i ogólnie dostępnych procedur terapeutycznych, optymalizacja wskazań terapii), optymalizację i wprowadzanie nowych zastosowań niefarmakologicznych form leczenia (radioterapia, chirurgia), a także leczenia skojarzonego z udziałem kilku metod (np. radiochemioterapia, okołooperacyjna chemioterapia i inne). W obliczu unijnego rozporządzenia, które wskazuje w preambule [1], że „aby w sposób maksymalny wykorzystać wartościowy wkład (...) sponsorów niekomercyjnych oraz aby nadal zachęcać ich do prowadzenia badań naukowych (...), państwa członkowskie powinny podejmować środki w celu wspierania badań klinicznych prowadzonych 
przez tych sponsorów" konieczne jest podjęcie krajowych działań legislacyjnych. Niekomercyjne badania kliniczne są źródłem wielu wartościowych publikacji naukowych w znaczących czasopismach międzynarodowych o istotnym wskaźniku wpływu (impact factor, IF), ich rozwój przyczyni się do wzrostu pozycji naukowej Polski w medycynie. Firmy farmaceutyczne często są gotowe do udostępnienia produktu leczniczego na rzecz badań akademickich, więc dostęp pacjentów do nowych kosztownych terapii w ramach niekomercyjnych badań klinicznych jest znacznym zyskiem dla systemu ochrony zdrowia, porównywalnym z kosztami pojedynczych programów lekowych. Jednym z podstawowych celów prowadzenia niekomercyjnych badań klinicznych jest zapewnienie pacjentom dostępu do niezbędnych terapii.

Omawiane rozporządzenie reguluje wiele istotnych kwestii związanych z prowadzeniem badań klinicznych, tych komercyjnych, jak i niekomercyjnych w krajach członkowskich Unii Europejskiej. Jednakże sukces i powodzenie ustanowionych przez Parlament Europejski przepisów zależy od szybkiej i prawidłowej implementacji w poszczególnych krajach UE, w tym w Polsce. Biorąc pod uwagę konieczność zmian legislacyjnych, towarzystwa onkologiczne w naszym kraju zaproponowały rozwiązania mające na celu usprawnienie realizacji niekomercyjnych badań klinicznych w Polsce:

1. Precyzyjne określenie, że badany produkt leczniczy i procedury w niekomercyjnych badaniach klinicznych stanowiące standard postępowania są finansowane w ramach powszechnego ubezpieczenia zdrowotnego, tak jak ma to miejsce w wielu krajach UE, dotyczy to również leczenia znanych działań niepożądanych terapii.

2. Konieczność zawierania ubezpieczeń na zasadach określonych w ustawie <Prawo farmaceutyczne $>$ [2] stanowi istotną barierę finansową dla podmiotów zaangażowanych w niekomercyjne badania kliniczne. Stosowanie sztywnych zasad, opartych jedynie na kwotach ubezpieczenia i liczbie uczestników badania klinicznego, nie uwzględnia specyfiki wszystkich rodzajów badań klinicznych. W przypadku wszystkich badań klinicznych zasadne jest rozpatrzenie wprowadzenia rozwiązań opartych o zasadę oceny ryzyka, tym bardziej że zastosowanym w rozporządzeniu UE kryterium rozróżnienia badań klinicznych jest właśnie ryzyko i stopień interwencji badań klinicznych. W odniesieniu do niekomercyjnych badań klinicznych zasadne jest również rozważenie wprowadzenia innych sposobów realizacji obowiązku ubezpieczeniowego. Przykładowo możliwa jest lub rezygnacja z dodatkowych ubezpieczeń. Szczególnie wskazana jest rezygnacja z dodatkowych ubezpieczeń w przypadku low-intervention trials wg definicji OECD (kategoria A i B1) [3]. Zgodnie z treścią dyrektywy 2005/28/WE warunkiprzeprowadzania badań niekomercyjnych przez badaczy niezależnych orazplaców- ki, w których przeprowadzane sq badania kliniczne, sprawiaja, iż stosowanie niektórych szczegółów dobrej praktyki klinicznejjest zbędne lub zagwarantowane winny sposób.

3. Rozporządzenie wskazuje, że państwa członkowskie mogą ustanawiać niższe opłaty za prowadzenie niekomercyjnych badań klinicznych oraz stosować zwolnienia z opłat za przeprowadzenie inspekcji. Opłaty związane z uzyskaniem pozwolenia na prowadzenie niekomercyjnych badań klinicznych stanowią w szeregu przypadków nieuzasadnione utrudnienie dla podmiotów, które chciałyby prowadzić tego typu badania. Proponujemy zniesienie lub znaczną obniżkę tych opłat w przypadku niekomercyjnych badań klinicznych.

4. Brak źródła finansowania przeznaczonego wyłącznie dla niekomercyjnych badań klinicznych. Pozyskiwanie środków na ich prowadzenie odbywa się, co do zasady, w trybach konkursowych lub grantowych. Istniejące instrumenty wsparcia finansowego (np. w ramach Narodowego Centrum Badań i Rozwoju) nie zawierają wydzielonej puli środków na prowadzenie niekomercyjnych badań klinicznych (i dotyczą tylko specyficznych sytuacji niezarejestrowanych potencjalnych terapii). Zasadne jest więc stworzenie specjalnego mechanizmu wsparcia dla niekomercyjnych badań klinicznych (w formie konkursowej), który zapewniałby ich finansowanie lub współfinansowanie. Przykładem może być National Clinical Research Program, funkcjonujący we Francji, czy programy funkcjonujące w Wielkiej Brytanii.

\section{Podsumowanie}

Istotna poprawa sytuacji w zakresie realizacji badań klinicznych przyniesie zwiększenie rangi naukowej Polski w dziedzinie nauk medycznych poprzez umożliwienie krajowych badań naukowych oraz współpracę w ramach europejskich sieci akademickich; współpraca międzynarodowa jest istotna $w$ dobie terapii celowanych dla subpopulacji pacjentów oraz terapii pacjentów z nowotworami rzadkimi; realizacja niekomercyjnych badań klinicznych w Polsce może wiązać się z uzyskaniem realnych korzyści finansowych w optymalizacji wydatków na nowe i kosztowne metody leczenia.

\section{Prof. dr hab. n. med. Piotr Rutkowski}

Klinika Nowotworów Tkanek Miękkich, Kości i Czerniaków Centrum Onkologii — Instytut im. Marii Skłodowskiej-Curie ul. Roentgena 5, 02-781 Warszawa e-mail:rutkowskip@coi.waw.pl

\section{Piśmiennictwo}

1. Rozporządzenie Parlamentu Europejskiego i Rady (UE) nr 536/2014 z dnia 16 kwietnia 2014 roku w sprawie badań klinicznych produktów leczniczych stosowanych u ludzi oraz uchylenia dyrektywy 2001/20/WE.

2. Ustawa <Prawo farmaceutyczne> z dnia 6 września 2001 roku z późniejszymi zmianami.

3. OECD Recommendation on the Governance of Clinical Trials. OECD 2013 